\title{
SERBSKIE KRĘGI FINANSOWE W CHORWACJI NA PRZEŁOMIE XIX I XX WIEKU. KONTEKST SPOŁECZNO-POLITYCZNY
}

\author{
JęDRZeJ PaszKiewicz
}

\begin{abstract}
Serbian financial elites in Croatia at the turn of the 19th century. Socio-political context The article decribes the circumstances of the emergence of the Serbian financial elites within the autonomous Kingdom of Croatia-Slavonia at the turn of the 19th century, taking into consideration the circles which provided financial and credit services at that time. The role of the Serbian financial elites is discussed from the perspective of their economic activity, social and political affiliations. The discussion includes the context of the dual autono$m y$ in the legal and political field, which regulated the status of the Kingdom of Croatia-Slavonia, the Patriarchate of Karlovci, and determined the overall situation of the Orthodox Serbs.

The reflection on the influence of the financial elites on the social and political modernisation processes among the Serbian population of the then Croatian autonomy is created on the basis of the the Serbian Bank in Zagreb programme assumptions (Srpska banka; 1895-1918), which was the most prominent financial establishment associated with the Serbian capital within Austria-Hungary.
\end{abstract}

STRESZCZENIE. W artykule zostały przedstawione okoliczności, w których doszło do wykrystalizowania się serbskich elit finansowych w autonomicznym Królestwie Chorwacji i Sławonii, na przełomie XIX i XX wieku. Pod uwagę wzięto środowiska, które w tym czasie prowadziły działalność finansowo-kredytową. Rola serbskich elit finansowych jest charakteryzowana pod kątem działań ekonomicznych i powiązań społeczno-politycznych. W opisie uwzględniono kontekst "podwójnej autonomii" prawno-politycznej”, w których ówcześnie funkcjonowali prawosławni Serbowie, dotyczącej statusu Królestwa Chorwacji i Sławonii oraz patriarchatu w Karlovcach. Na podstawie analizy założeń programowych Banku Serbskiego z Zagrzebia (Srpska banka; 1895-1918), największej instytucji finansowej, która była kojarzona z serbskim kapitałem w Austro-Węgrzech, przeprowadzona jest refleksja nad wpływem omawianych elit na proces modernizacji społecznej i politycznej ludności serbskiej z obszaru ówczesnej Chorwacji.

Autor: Jędrzej Paszkiewicz, Uniwersytet im. Adama Mickiewicza, Wydział Historyczny, ul. Umultowska 89d, 61-614 Poznań, Polska, prosinac@amu.edu.pl, ORCID iD: https://orcid.org/0000-0002-7115-9284

Slowa kluczowe: Serbowie, Austro-Węgry, Chorwacja, elity finansowe

Keywords: Serbs, Austro-Hungary, Croatia, financial elites

Balcanica Posnaniensia. Acta et studia, XXV, Poznań 2018, Wydawnictwo Instytutu Historii UAM, pp. 113-127, ISBN 978-83-65663-94-8, ISSN 0239-4278. Polish text with summaries in English and Polish.

doi.org/10.14746/bp.2018.25.7 
Proces tworzenia się środowisk związanych z działalnością finansowo-kredytową wśród Serbów, zamieszkujących tzw. ziemie chorwacko-sławońskie, przypadł na drugą połowę XIX wieku' ${ }^{1}$ Prawne warunki działalności miejscowej administracji oraz kół polityczno-gospodarczych były wyznaczane przez tzw. ugodę chorwacko-węgierską z 1868 roku (chorw. hrvatsko-ugarska nagodba; węg. magyar-horvát kiegyezés), która sankcjonowała węgierskie zwierzchnictwo polityczno-ekonomiczne nad tym obszarem a jednocześnie dopuszczała istnienie autonomicznego systemu rządów, ujętego w polityczne klamry Królestwa Chorwacji i Słowenii. Okres, gdy banami byli Ivan Mažuranić (1873-1880), Ladislav Pejačević (1880-1883) i Károly Khuen Hedervary (1883-1903) to czas znaczących zmian społecznych i politycznych, które dotyczyły wszystkich grup narodowościowych, zamieszkujących omawiany rejon. Najwięcej Serbów znajdowało się w żupanii sremskiej i Pograniczu Wojskowym, które ostatecznie zostało zlikwidowane w 1881 roku i włączone do granic autonomicznego tworu politycznego, administrowanego przez banów rezydujących w Zagrzebiu. Jednocześnie, w stosunku do ludności serbskiej utrzymano instytucję patriarchatu (istniejącego od 1848 roku) w Karlovcach (pol. Sremski Karlovci lub Karłowice, serb. Sremski Karlovci; węg. Karlóca; niem. Karlowitz), która dysponowała autonomią w sprawach religijnych i edukacyjnych. Patriarchat sprawował opiekę nad serbską ludnością prawosławną w ramach prowincji kościelnej, usankcjonowanej przez monarchię habsburską. Serbska autonomia kościelno-szkolna na ziemiach chorwackich została uprawomocniona w 1887 roku, na mocy uchwały przyjętej sabor chorwacki (Srpski zakon) $)^{2}$. Wbrew oczekiwaniom wielu osób związanych z serbskimi elitami politycznymi, w oficjalnej dokumentacji ludności, która wówczas podlegała jurysdykcji patriarchatu, nie określono jednak jako Serbów, ale jako ludność grecko-wschodnią (grčko-istočna). Tym samym zwracano uwagę na religijną, a nie narodową legitymację odrębności prawno-edukacyjnej serbskich społeczności, żyjących w Królestwie Chorwacji i Slawonii ${ }^{3}$.

W latach dziewięćdziesiątych XIX wieku szacowano, że ludność serbska zamieszkujaca obszar Chorwacji-Sławonii, stanowiła nawet 1/4 wszystkich mieszkańców (za

${ }^{1}$ Tzw. chorwacka autonomia, o nazwie Trójjedyne Królestwo Chorwacji, Slawonii $i$ Dalmacji (chorw. Kraljevina Hrvatska i Slavonija; 1868-1918), obejmowała osiem jednostek administracyjnych, zwanych żupaniami: Bjelovar-Križevci, Lika-Krbava, Modruš-Rijeka, Požega, Srijem (Srem), Varaždin, Vitrovitica, Zagrzeb. W literaturze przedmiotu na określenie tego tworu politycznego w omawianym okresie używa się także bardziej potocznych nazw Trojednica lub bańska Chorwacja (banska Hrvatska); D. Čepulo, Hrvatska pravna povijest u europskom kontekstu od srednjeg vijeka do suvremenog doba, Zagreb 2016, s. 171-172.

2 Срби у Хабзбуршкој Монархији од 1526. до 1918., Нови Сад 2016, t. 2, s. 317-318.

${ }^{3}$ Zakon o uređenju crkve grčko-iztočne i porabi ćirilice u kraljevinama Hrvatskoj i Slavoniji od 14. svibnja 1887. godine, Hrvatski ustavni zakoni, Zagreb 1917, s. 432-433. R. Grujić, Azbučnik Srpske pravoslavne crkve, Beograd 1993, s. 114-139; G. Krivokapić-Jović, Srbi u Kraljevini Hrvatskoj i Slavoniji na prelomu 19. u 20. stoleće - vreme stvaranja „Privrednika”, w: Srpsko privredno društvo "Privrednik”. Kroz tri vijeka, red. Nikola Lunić, Jelena Tabaks, Novi Sad 2009, s. 85-86. 
rok 1900, 25,52\%) ${ }^{4}$. Największą koncentrację mieszkańców serbskiego pochodzenia odnotowano na terenie żupanii Lika-Krbava - stanowili oni ponad 50\% ogółu ludności, przeważnie żyli na rejonach wiejskich. Z kolei w żupanii sremskiej procentowy udział Serbów szacowano na blisko 46\%, przy czym ludność ta charakteryzowała się stosunkowo dużym zróżnicowaniem społeczno-ekonomicznym ${ }^{5}$. W szczególności należy odnotować relatywnie dużą koncentrację Serbów w ośrodkach miejskich. Właśnie tam najwcześniej pojawiły się środowiska, prowadzące działalność finansową ${ }^{6}$.

W następstwie istnienia zróżnicowanej społecznie ludności, a także działalności autonomicznych struktur kościelnych, aktywnie oddziałujących na relacje społeczne i ekonomicznie, żupania sremska była najbardziej zaawansowana pod względem rozwoju gospodarczego rejonem monarchii, zasiedlonym przez zwarte grupy ludności serbskiej. Ważne było, że w rezultacie zmian granic patriarchatu pod koniec XIX wieku, granice poszczególnych diecezji w zasadzie pokrywały się z cywilnymi podziałami administracyjnymi na ziemiach chorwacko-sławońskich ${ }^{7}$. Dawało to środowiskom ekonomicznym, powiązanym z interesami hierarchii prawosławnej, dogodny punkt wyjścia do ugruntowania i poszerzenia swojej aktywności. Pierwsze instytucje finansowe, współtworzone przez serbskich przedsiębiorców i kupców, powstawały wyłącznie w Sremie pod koniec lat sześćdziesiątych XIX wieku. Ich działalność była

\footnotetext{
${ }^{4}$ M. Artuković, Srbi u Hrvatskoj: Statistički pokazatelji (1883.-1903.), „Časopis za suvremenu povijest", 2000, nr 1, s. 138.

${ }^{5}$ Według danych statystycznych za lata 1880 i 1900, najwięcej Serbów zamieszkiwało żupanię sremską (134 588 w 1880 r. i 166717 w 1900 r.), gdzie jednak stanowili oni niespełna połowę tamtejszej ludności (47,21\% i 45,71\%). Zwarte grupy ludności serbskiej zasiedlały także żupanię Lika-Krbava i tam Serbowie stanowili większość (50,32\% i 51,24\%). Dominowali przeważnie na terenach, przylegających do granicy z Bośnią, np. w gminach Donji Lapac (91,40\%; 91,71\%), Korenica $(74,48 \%$; 74,17\%), Udbina $(71,09 \% ; 70,93 \%)$ czy Gračac $(69,69 \% ; 70,52 \%)$. Ludność serbska zasiedlała pas przygraniczny także w żupaniach położonych na wschód od Liki i Krbawy, tam jednak znajdowała w mniejszości. I tak, udział Serbów w ogóle ludności z żupanii Modrus-Rijeka wynosił, wedle danych za lata 1880 i 1900, 31,74\% i $32,23 \%$, w żupanii Pożega $27,77 \%$ i $25,79 \%$ a w żupanii zagrzebskiej $22,39 \%$ i $23,79 \%$. W żupanii zagrzebskiej Serbowie wyraźnie dominowali w czterech kotarach: Dvor $(87,35 \% ; 88,00 \%)$, Vrginmost/ Gvozd $(85,63 \% ; 86,12 \%)$, Glina $(63,27 \% ; 64,82 \%)$ i Kostajnica $(59,60 \% ; 62,29 \%)$. Z kolei w Zagrzebiu statystyki odnotowały niespełna tysiąc osób serbskiego pochodzenia. Byli to urzędnicy, oficerowie, kupcy, stanowiący w 1880 roku 3,29\% a dwadzieścia lat później 4,22\% wszystkich mieszkańców miasta). W sławońskiej żupanii Vitrovitica, procentowy udział ludności serbskiej ustalono odpowiednio na 21,09\% i 18,70\%; Statistički godišnjak kraljevina Hrvatske i Slavonije, 1905, Zagreb 1913, s. 34-39. Spośród wszystkich miast, największy odsetek serbskiej ludności odnotowano w Karlovcach (56\%), Mitrovicy (38\%), Zemunie (36\%); A. Szabo, Socijalna struktura srpskog stanovnistva u Hrvatskoj i Slavoniji izmedu 1880 i 1900. godine, w: Zbornik radova o povijesti i kultury srpskog naroda u Socijalistickoj Republici Hrvatskoj, Zagreb 1989, t. 2, s. 108.

${ }^{6}$ В. Ђ Крестић, Историја Срба у Хрватској и Славонији, Београд 2010, s. 363-364. Prawną podstawę dla działalności podmiotów finansowych stanowiły ustawy handlowa $(1875$; art. 37) oraz o spółdzielniach kredytowych i pożyczkowych (1896, art. 23); Срби у Хабзбурикој Монархији, s. 326.

${ }^{7}$ Por. N. Rumenjak, Politička i društvena elita Srba u Hrvatskoj potkraj 19. stoljeća: uspon i pad Srpskoga kluba, Zagreb 2005. s. 19.
} 
związana ze zachodzacą stopniowo, opóźnioną w stosunku do innych części państwa, modernizacją relacji ekonomicznych, opartych na gospodarce pieniężno-kredytowej. Najczęściej były to skromne kapitałowo kasy oszczędnościowe, nastawione na obsługę mieszkańców miast, utrzymujących się z rzemiosła i handlu. Były obliczone na niewielką skalę i ograniczone zyski, w związku z relatywnie niewielkim popytem na usługi finansowe ze strony ogółu ludności. Wiele upadło na początku lat siedemdziesiątych XIX wieku, w następstwie kryzysu finansnowego w monarchii. Te, które przetrwały, w kolejnych dziesięcioleciach zmieniały formułę działalności. Pojawiły się kasy spółdzielcze i spółki akcyjne, które oprócz prowadzenia rachunków oszczędnościowych zarabiały na udzielaniu niewielkich kredytów krótkoterminowych. Pod koniec lat osiemdziesiątych XIX wieku na terenie żupanii sremskiej odnotowano działalność kilkunastu takich instytucji, związanych z ludnością serbską zamieszkującą Karlovci, Mitrowicę, Zemun, Vukovar czy Rumę ${ }^{8}$. Z kolei w 1900 roku, łączną liczbę instytucji finansowych z udziałem serbskiego kapitału, operujących na terenie całej tzw. bańskiej Chorwacji (łącznie z Rijeką i Međumurjem) obliczano na 35 podmiotów, co stanowiło $16,6 \%$ wszystkich przedsięwzięć tego typu9 9

Wspomniane kasy oszczędnościowe miały rację bytu tylko tam, gdzie Serbowie żyli w stosunkowo dużym zagęszczeniu i odnajdywali się w realiach ówczesnej pospodarki pieniężnej. Bez wątpienia, popyt na usługi finansowe w żupanii sremskiej i wschodniej części Sławonii zwiększył się w następstwie likwidacji Pogranicza Wojskowego. Miejscowi kupcy i przedsiębiorcy musieli stawić czoło zmienionym warunkom ekonomicznym. Warunki prowadzenia wymiany skomplikowały się, wymuszając na lokalnych środowiskach ekonomicznych konieczność zwarcia szeregów. Przede wszystkim wzrosło znaczenie handlu z Bośnią (m.in. przez Osijek i Vukovar), również w następstwie wzrostu konkurencji ze strony środowisk austriacko-węgierskich oraz chorwackich. Miejscowe kasy oszczędnościowe musiały podjąć działania w kierunku większej profesjonalizacji usług i szukały nowych źródeł ich finansowania, łącząc się $\mathrm{w}$ większe struktury lub zmieniając status prawny ${ }^{10}$. $\mathrm{Z}$ drugiej strony

${ }^{8}$ Pierwsze kasy oszczędnościowe z udziałem serbskiego kapitału tworzono w Zemunie (1867), Sremskiej Mitrovicy i Vukovarze (1869), Sremskich Karlovcach (1871), Rumi (1872), Vinkovci (1873), mieście Šid (1884). Pierwsze kasy oszczędnościowe z udziałem serbskiego kapitału stworzono w Zemunie (1867), Sremskiej Mitrovicy i Vukovarze (1869), Karlovcach (1871), Rumi (1872), Vinkovci (1873) i w mieście Šid (1884). Z kolei pierwsza spółdzielnia oszczędnościowa powstała po przekształceniu kasy z Karlovców (1875). Kolejne działały w Starej Pazovej (1882), miejscowości Golubinci (1887), Karlovcach (1885) oraz w mieście Irig (1888). Część wkrótce zmieniła formułę, przekształcając się w spółki akcyjne; N. Rumenjak, Politička i društvena elita Srba, s. 489-491.

${ }^{9}$ Ibidem, s 204; A. Radenić, Položaj i borba seljaštva u Sremu od kraja XIX veka do 1914, Beograd 1958, s. 43-44.

${ }^{10}$ M. Gross, A. Szabo, „Prema hrvatskom građanskom društvu”: društveni razvoj u civilnoj Hrvatskoj i Slavoniji šezdesetih i sedamdesetih godina 19. stoljeća, Zagreb 1992, s. 348. Na ukonstytuowanie się nowych elit serbskich w żupanii sremskiej wpłynął stosunkowo duży udział serbskiej ludności w ośrodkach miejskich. Poza tym istniały tradycyjne powiązania między tymi ośrodkami a serbskimi „koloniami” kupieckimi z Węgier południowych oraz z rynkiem serbskim (pośrednictwo w handlu 
zazwyczaj unikano ryzykownych posunięć finansowych, dbając przede wszystkim o regularne wypłaty dywidend dla udziałowców. Działalność inwestycyjna nie była przedmiotem zainteresowania tych podmiotów, ponieważ uznawano ją za nazbyt ryzykowną i mało perspektywiczną, zwłaszcza w rejonach zdominowanych przez niewielkie gospodarstwa rolne ${ }^{11}$.

O ile instytucje finansowe, działające w żupanii sremskiej, przeważnie były powiązane z miejscową elitą polityczną i społeczną, dobrze odnajdującą się w kontaktach ze strukturami patriarchatu i władzami austro-węgierskimi, inaczej sytuacja ta wyglądała w innych rejonach tzw. bańskiej Chorwacji. W tym przypadku zauważalna była ekonomiczna słabość żywiołu serbskiego, który był skupiony na terenach wiejskich w Lice, Kordunie oraz w środkowej Sławonii. Na tym obszarze dominował handel i rzemiosło nastawione wyłącznie na obsługę odbiorcy lokalnego. Popyt na usługi finansowe ze strony tamtejszej ludności był minimalny, ze względu na anachroniczny, na wpół autarkiczny charakter relacji gospodarczych, powiązanych z systemem niewielkich gospodarstw rodzinnych (porodične zadruge) ${ }^{12}$. Ten tradycyjny system gospodarowania został ostatecznie unieważniony w związku z likwidacją Pogranicza Wojskowego. Większość tamtejszej ludności chłopskiej nie była w stanie sprostać nowym warunkom ekonomicznym, oznaczającym otwarcie obszaru znajdującego się dotychczas w szczególnej sytuacji prawno-administracyjnej na działania mechanizmów rynkowych, obowiązujących w monarchii. W nowej sytuacji zaczęto odczuwać brak kapitału, za pomocą którego można by dostosować miejscową gospodarkę do nowych wyzwań ekonomicznych. Kasy oszczędnościowo-pożyczkowe ze Sremu nie były przygotowane do obsługi ludności z byłego Pogranicza. Zadowalały one głównie potrzeby kredytowe kupców, rzemieślników i bogatszego chłopstwa. Tymczasem większość Serbów, przeważnie żyjących w biednych wsiach Pogranicza, potrzebowała podstawowego wsparcia finansnowego, aby przetrwać w warunkach zaostrzającej się konkurencji ekonomicznej ${ }^{13}$.

Problemy te były przedmiotem zainteresowania środowiska polityczno-gospodarczego, które pod koniec XIX wieku ukształtowało się w Zagrzebiu. Było ono kojarzone z pochodzącym z Pogranicza Wojskowego kupcem i politykiem serbskiego pochodzenia, Vladimirem Matijeviciem. W grupie tej znalazły się różne postaci, związane z najważniejszymi ośrodkami serbskiego życia polityczno-gospodarczego, także spoza Austro-Węgier. Obok V. Matijevicia, który doświadczenie ekonomiczne i spory kapitał zdobył prowadząc interesy handlowe w monarchii, wymienia się serbskiego polityka Kostę S. Taušanovicia oraz osoby pochodzące ze Sławonii, Sremu lub

\footnotetext{
zwierzętami). To dynamizowało obrót handlowy w żupanii i przekładało się na większe obroty finansowe. Nadwyżki finansowe mogły być lokowane w przedsięwzięciach o charakterze parabankowym lub bankowym; N. Gaćeša, Srpske novčane ustanove u drugoj polovici XIX i početkom XX veka u Hrvatskoj i Slavoniji, w: Zbornik o Srbima u Hrvatskoj, red. V. Krestić, Beograd 1999, t. 4, s. 121.

${ }^{11}$ N. Rumenjak, Politička i društvena elita, s. 488.

${ }^{12}$ M. Gross, A. Szabo, „Prema hrvatskom građanskom društvu”, s. 344-348; Đ. Stanković, „Privrednik" i Srbi u Slavoniji na razmeđu vekova, w: Srpsko privredno društvo, s. 50.

${ }^{13}$ D. Jelić, Sailing with the nationalist wind, s. 154.
} 
Węgier południowych, ziemianina Vasę Muačevicia z Osijeku, przedsiębiorcę Lazara Dunđerskiego z Nowego Sadu czy finansistów oraz prawników, Aćima Đermanovicia oraz Đjorđe Velisavljevicia ${ }^{14}$. Dzięki działaniom tego środowiska, w 1895 roku stworzono precedensową w ówczesnych warunkach inicjatywę ekonomiczną o nazwie Serbski bank w Zagrzebiu (Srpska banka u Zagrebu). Przyjęta przez założycieli filozofia działania tej instytucji znacząco wpłynęła na tranformację odniesień ekonomicznych wśród Serbów, przede wszystkim z obszarzu byłego Pogranicza Wojskowego. Od samego początku aktywność banku była przez założycieli definiowana w wymiarze komercyjnym oraz politycznym. Podkreślali oni narodowy charakter przedsięwzięcia, którego celem była modernizacja życia gospodarczego na ziemiach zasiedlonych przez Serbów, a w dalszej perspektywie integracja ludności, żyjącej na terytorium całej monarchii, wokół ogólnie pojętego interesu narodowego w wymiarze ekonomicznym ${ }^{15}$.

Nieodłącznym elementem funkcjonowania serbskich elit finansowych w AustroWęgrzech było ich powiązanie z praktyką administracyjną i polityczną monarchii, opartą na autonomicznym statusie ziem chorwacko-sławońskich. Obecność osób piastujących stanowiska publiczne w ciałach zarządzających kasami a następnie bankami, była oczywistością. Zapewniały one stabilne relacje z władzami, ułatwiały lawirowanie w skomplikowanej materii prawno-fiskalnej. W działaniach instytucji finansowych, kojarzonych z serbskim kapitałem, dużą rolę odgrywały osoby powiązane z władzą żupańską i gminną. W Zagrzebiu, o interesy serbskich finansistów ze Sremu dbali wysoko postawieni działacze prowęgierskiej Partii Narodowej, tacy jak wiceban Jovan Živković (1873-1883), przewodniczący saboru Nikola Krestić (1873-1884) czy Livije Radivojević, stojący na czele królewskiego sądu najwyższego (1874-1891). W 1895 roku L. Radivojević stanął także na czele banku serbskiego w Zagrzebiu, jako jego prezes honorowy ${ }^{16}$.

${ }^{14}$ N. Rumenjak, Politička i društvena elita, s. 488-489. O działalności społeczno-gospodarczej V. Matijevicia pisali m.in.: M. Vučković, M. Žuravčić, Pedeset godina Srpskog privrednog društva ,Privrednik”, w: Spomen knjiga Srpskog privrednog društva Privrednik 1897-1947, Beograd 1984. s. V-XLII.

15 Por. Pet godina rada Srpske banke, "Privrednik”, 1900, nr 13, s. 154-155. Bank podjął działalność 1 lipca 1895 roku. Początkowy kapitał wynosił 3060000 koron. Tylko 94 udziałowców banku mogło bezpośrednio wpływać na działalność banku poprzez rade nadzorczą i zarządzającą, jako ze mieli oni od 50 do 500 akcji. Wśród najważniejszych udziałowców, którzy byli w posiadaniu powyżej 200 akcji, występowała spółdzielnia na rzecz międzyosobowej pomocy i oszczędności (Sremsko-karlovačka zadruga za međusobno pomaganje i štednju), założona dziesięć lat wcześniej w Karlovcach przez działaczy klubu serbskiego przy poparciu hierarchii duchownej, która była zaniepokojona aktywnością finansową partii autonomistycznej w Karlovcach. Przedstawicielstwa banku ulokowano w Nowym Sadzie, Somborze, Suboticy, Sremskiej Mitrovicy, Kninie, a także w Splicie, Šibeniku i Dubrowniku; N. Gaćeša, Srpske novčane ustanove, s. 122, 125-129; P. Krestić, Vladimir Matijević i društvo "Privrednik", w: Srpsko privredno društvo, s. 20.

${ }^{16}$ D. Jelić, Sailing with the nationalist wind: the case of the Serbian bank in Zagreb (1895-1918), $\mathrm{w}$ : The creators and the creation of banking enterprises in Europe from the 18th to the 20th century, red. K. P. Kostis, Athens 2002, s. 155. 
Dowodów na duży wpływ środowisk tradycyjnie dominujących w życiu społeczno-politycznym monarchii na relacje finansnowe w Chorwacjo-Sławonii dostarcza analiza akcjonariatu Serbskiego Banku, który od czasu powstania uchodził za swoistą emanację kształtujących się serbskich elit finansowych. I tak, większość przedstawicieli tej grupy uczestniczyła w pracach patriarszego zgromadzenia kościelno-narodowego w Karlovcach (народно-ирквени сабор) lub saboru zagrzebskiego. Przeważali majętni arystokraci, duży odsetek stanowiły osoby powiązane ze strukturami urzędniczo-politycznymi monarchii (16\%), przedstawiciele wolnych zawodów (12\%) i duchowni $(12 \%)^{17}$. Stosunkowo niewielu było przedsiębiorców i kupców. Ogółem, osoby prowadzące jakąkolwiek działalność gospodarczą stanowiły nieco ponad $40 \%$ akcjonariuszy banku. Bez wątpienia, skład tej grupy odpowiadał ówczesnym podziałom społecznym w Chorwacji i Sławonii, gdzie dominowała tradycyjna gospodarka rolna, oparta na nielicznych wielkich majątkach ziemskich oraz drobnych gospodarstwach chłopskich. Wiele aspektów życia gospodarczego nadal znajdowało się pod kontrolą państwowej biurokracji, cywilnej i wojskowej. Tym należy tłumaczyć duży udział arystokracji i osób powiązanych z władzami w strukturach nowo powołanego banku ${ }^{18}$.

W rezultacie, losy serbskich elit finansowych rozstrzygały się w trakcie kolejnych kampanii elektorskich do zgromadzenia religijno-narodowego. Rywalizacja ta często jest opisywana w literaturze przedmiotu w kategoriach walki między rzecznikami utrzymania tradycyjnych podziałów społecznych, stojącymi na straży interesów monarchii i serbskiej hierarchii duchownej ze środowiskami, które prezentowały bardziej liberalne podejście do życia społeczno-ekonomicznego. Istotnie, zwolennicy gospodarki rynkowej stanowili naturalne zaplecze dla grup postulujących sekularyzację stosunków społeczno-politycznych wsród ludności serebskiej. Z drugiej strony, wiele instytucji, które były ważne dla rozwoju nowoczesnej gospodarki pieniężnej w tzw. bańskiej Chorwacji utrzymywało się dzięki funduszom pochodzącym ze źródeł patriarszych lub powiązanych ze strukturami władzy. Sytuacja ta zaczęła ulegać stopniowej zmianie w związku z nasilającym się wpływem władz węgierskich w zakresie zarządzania sprawami administracyjnymi, w tym także funduszami patriarchatu. I tak, w 1882 roku, po wyborze patriarchy Germana Anđelicia, przyjęto przepisy, zgodnie z którymi wszystkie decyzje karłowickiego zgromadzenia w sprawach finansowych musiały zyskać kontrasygnatę przedstawicieli rządu. W rezultacie, działalność ekonomiczna instytucji patriarszych w większej mierze sprzyjała interesom węgierskich, a nie serbskich kół gospodarczych. Realizację zadań finansowych patriarchatu z Karlovców powierzono w latach 1892-1907 bankowi reprezentującemu przede wszystkim kapitał węgierski (Hrvatsko-slavonska hipotekarna banka), co uderzyło w lokalne instytucje finansowe, współtworzone przez Serbów. Sytuacja ta zradykalizowała część środowisk serbskich z żupanii sremskiej, tworząc grunt pod stop-

\footnotetext{
17 N. Rumenjak, Politička i društvena elita Srba, s. 496-497.

18 N. Gaćeša, Srpske novčane ustanove, s. 124.
} 
niowy wzrost znaczenia ruchów narodowych, działających wśród ludności serbskiej od początku lat osiemdziesiątych - radykalnego i autonomistycznego ${ }^{19}$. Tzw. radykałowie współpracowali z Narodową Partią Radykalną (Narodna radikalna stranka; 1881) z Serbii, z kolei rzecznicy ruchu serbskich autonomistów, zwani samostalcami (Srpska samostalna stranka) podkreślali konieczność laicyzacji odniesień, organizujących życie społeczno-polityczne Serbów z monarchii habsburskiej i przyjęcia nowych regulacji prawnych, określających odrębność tej ludności. Szczególny nacisk kładli oni na działalność polityczną w ramach karłowickiego zgromadzenia kościelno-narodowego ${ }^{20}$. Ugruntowanie pozycji tych środowisk w serbskim życiu społeczno-politycznym przypadło jednak dopiero na początek XX wieku. Wcześniej, np. w pierwszym dziesięcioleciu rządów bana K. Khuen-Héderváry’ego (1883-1903) szacowano, że ponad połowa Serbów, związanych z działalnością finansową i kupiecką z Chorwacji-Sławonii, wspierała ówczesny reżim polityczny, współtworzony przez tzw. unionistów (Partia Narodowa; Narodna stranka), a więc zwolenników ścisłej współpracy z Węgrami. Generalnie grupa ta akceptowała także działania władz, naciskających na patriarchat, aby prowadził zdecydowaną walkę z opozycją polityczną ${ }^{21}$.

Pracownicy i przedstawiciele serbskich instytucji finansowych często byli aktywnymi uczestnikami procesów politycznych, takich jak wybory do saboru chorwackiego, zgromadzenia kościelno-narodowego lub nominantami na przedstawicieli władzy żupańskiej. Zdarzało się, że poszczególne instytucje finansowe przejmowały rolę kredytodawców dla bieżącej działalności politycznej, prowadzonej przez poszczególne środowiska polityczne. W największym stopniu działania te były widoczne w żupanii sremskiej, zwłaszcza w miastach, gdzie ludność serbska wykazywała największą aktywność na polu społeczno-politycznym (Karlovci, Mitrovica, Vukovar) ${ }^{22}$. I tak, kontekst polityczny zaciążył chociażby na losach jednej z kas oszczędnościowych, aktywnie działającej w pierwszej połowie lat osiemdziesiątych XIX wieku w Karlovcach, którą kojarzono z interesami partii autonomistycznej. W 1885 roku, tuż przed wyobrami do zgromadzenia kościelno-narodowego, serbskie koła lojalistyczne, współpracujące z patriarchą G. Anđeliciem i banem K. Khuen-Héderváry’m, doprowadziły tę kasę do bankructwa. Przy poparciu władz stworzono konkurencyjną spółdzielnię, której kapitał oparto na funduszach klasztornych, zarządzanych przez patriarchat wespół z przedstawicielami rządu węgierskiego (Sremsko-karlovačka za-

19 Por. M. Gross, Vladavina Hrvatsko-srpske koalicije 1906-1907, Beograd 1960, s. 89, 137.

${ }^{20}$ Срби у Хабзбуршкој Монархији од 1526. до 1918., t. 2, Нови Сад 2016, s. 324.

${ }^{21} \mathrm{~W} 1883$ roku w chorwackim saborze powstał serbski klub parlamentarny. Jego członkowie w większości wywodzili się ze Sremu i eksponowali lojalistyczne stanowisko wobec monarchii austrowęgierskiej, w tym także bana K. Khuena Hedervary'ego. Z tego względu byli oni nazywani przez konkurentów politycznych "Serbami Khuena" (Khuenovi Srbi), Nierzadko współtworzyli oni instytucje finansowe w Sremie. Przychylność reżimu wobec serbskiej elity ze Sremu thumaczono dobrymi natenaczas stosunkami między Austro-Węgrami a Serbią Obrenoviciów; Срби у Хабзбурикој Монархији, s. 329.

${ }^{22}$ N. Rumenjak, Politička i društvena elita, s. 541. 
druga za međusobno pomaganje i štednju; 1885). Na mocy decyzji władz węgiersko-chorwackich, wszystkie jednostki kościelne, edukacyjne i kulturalne, działające w ramach tzw. serbskiej autonomii, musiały wówczas przekierować swoje fundusze do nowo stworzonej instytucji i założyć tam swoje rachunki. Co ciekawe, jeden z zarządców upadłej kasy wkrótce stał się członkiem zarządu konkurencyjnej spółdzielni, jako że w oczach jej założycieli uchodził za fachowca, w dodatku sprzyjającego interesom kół lojalistycznych ${ }^{23}$. Interesująca, z punktu widzenia sympatii politycznych, była także grupa, stojąca za Serbskim Bankiem z Zagrzebia. Choć jego założyciele, wśród nich V. Matijević, byli znani ze swych autonomistycznych poglądów, znaczącą część akcjonariatu stanowiły postaci i firmy utożsamiane ze środowiskami powiązanymi z patriarchatem oraz unionistami. Ci ostatni wpływali na działalność banku chociażby poprzez wspomnianą wcześniej spółdzielnię z Karlovców, która była jednym $\mathrm{z}$ najważniejszych akcjonariuszy ${ }^{24}$. Poważnym problemem dla realizatorów szeroko zakrojonego projektu bankowego, jakim był Serbski Bank w Zagrzebiu, była relatywnie niewielka liczba osób, które mogły podołać temu wyzwaniu zarówno pod względem finansowym, jak i przygotowania ekonomicznego. $Z$ tego powodu nie można było oprzeć tej struktury wyłącznie na przedstawicielach jednego środowiska politycznego. Konieczne było zaangażowanie wielu środowisk, a i tak regułą było, że poszczególne osoby dublowały poszczególne stanowiska w banku, jako że trudno było znaleźć wykwalifikowaną kadrę zarządzającą.

Powołanie Serbskiego Banku w Zagrzebiu uznaje się jako moment przełomowy dla rozwoju przedsiębiorczości finansowej, zorientowanej na serbskiego odbior-

23 Prowęgiersko nastawiona hierarchia duchowna i konserwatywni członkowie klubu serbskiego mieli decydujący wpływ na finanse serbskiej autonomii do 1897 roku, do czasu zwycięstwa opozycji. Radykałowie, którzy wówczas zdominowali karłowickie zgromadzenie, wspierali powołaną przez siebie spółdzielnię pieniężną w Karlovcach, którą na początku XX wieku przekształcili w spółkę akcyjną. W 1902 roku zdobyli oni faktyczną kontrolę nad funduszami kościelno-narodowymi; N. Rumenjak, Politička i društvena elita, s. 547; Срби у Хабзбуршкој Монархији, s. 326.

${ }^{24}$ Uwagę zwracał wpływ na organizację banku z Zagrzebia osób wywodzących się z różnych gremiów. I tak, wśród znaczących akcjonariuszy był przemysłowiec i finansista Lazar Dunđerski, założyciel m.in. Centralnego Zakładu Kredytowego z Nowego Sadu (Centralni kreditni zavod). Postać ta była utożsamiana ze środowiskami serbskimi z Węgier południowych, pozostającymi poza zasięgiem patriarchatu, o nastawieniu liberalnym. Nie do końca wyjaśnioną rolę w organizacji banku odgrywał Livije Radivojević (1821-1903). Choć od 1891 roku przebywał on na politycznej emeryturze (w latach 1874-1891 przewodniczył pracom naczelnego sądu w Zagrzebiu), uchodził za wpływowego polityka i wytrwanego znawcę spraw administracyjno-prawnych. Dużą rolę w organizacji banku mieli rzecznicy partii radykalnej, kupcy i finansiści, którzy zasiedli w radzie nadzorczej: J. Đurčić-Biorac z Rumy, Đ. Krasojević z Karlovców i Giga Avakumović z Zemuna. Istotne były kontakty z serbskimi środowiskami politycznymi i ekonomicznymi z Belgradu. Ważną postacią był polityk i bankier Kosta S. Taušanović (1854-1902), jeden z bliskich współpracowników Nikoli Pašicia. Ze względu na swoją działalność przeciwko dynastii Obrenoviciów, tymczasowo przebywał on terenie monarchii habsburskiej. Po powrocie do Belgradu odgrywał rolę swoistego przedstawiciela interesów banku w kontaktach z miejscowymi elitami politycznymi. Z jego inicjatywy rząd serbski miał partycypować finansowo m.in. w powołaniu czasopisma „Privrednik”, adresowanego do serbskich odbiorców w monarchii habsburskiej; N. Rumenjak, Politička i društvena elita Srba, s. 382, 396, 400; D. Jelić, Sailing with the nationalist wind, s. 152. 
cę. Podstawy banku częściowo oparto na wcześniej działających lokalnych kasach. Jednocześnie tworzono sieć spółdzielni pożyczkowo-oszczędnościowych, które łączono w związek kas, nadzorowany przez zagrzebską centralę. Rozwiązanie to, sprawdzone wcześniej na gruncie niemieckim (tzw. kasy Raiffeisena), korespondowało z podobnymi przedsięwzięciami finansowymi z terenu monarchii habsburskiej (por. Kasy Stefczyka, od 1890 roku ${ }^{25}$. Dzięki temu ludność serbska z terenów wiejskich zyskiwała łatwiejszy dostęp do tzw. małych, krótkoterminowych kredytów. Wkrótce stały się one jednym $z$ najpopularniejszych instrumentów finansowych w ofercie banku z Zagrzebia. Tworzenie gęstej sieci powiązań instytucjonalnych w sferze lokalnej sprawiło, że systematycznie wzrastała rola transakcji pieniężnych w codziennych relacjach ekonomicznych. Upowszechnienie kredytów, ułatwiających podjęcie działalności rzemieślniczej lub handlowej, wpłynęło ożywczo na życie gospodarcze w Lice, Kordunie i środkowej Sławonii. Dzięki rozwojowi instytucji finansnowych i spółdzielczych wzmacniały się kontakty między poszczególnymi środowiskami serbskimi, które wcześniej, w warunkach Pogranicza Wojskowego, funkcjonowały w ekonomicznej izolacji ${ }^{26}$. Szybko, w oparciu o podobny model ekonomiczny, na terenie Królestwa Chorwacjii Sławonii oraz w Bośni, zaczęły powstawać konkurencyjne instytucje, związane z serbskim kapitałem ${ }^{27}$. W rezultacie, głównym obszarem aktywności banku z Zagrzebia pozostały trzy żupanie z zachodniej części Chorwacji, zagrzebska, żupanie Lika-Krbava i Požega (Požeška županija). Prym pod względem liczby działających instytucji finansowych niezmiennie wiodła żupania sremska, ale pojawił się prężnie działający konkurent na tym polu.

Zadanie rozwinięcia nowoczesnych form życia społeczno-ekonomicznego wśród Serbów z byłego Pogranicza Wojskowego zostało podjęte przez ograniczoną liczebnie elitę serbskiego pochodzenia, która początkowo nie miała żadnego wsparcia instytucjonalnego. Jej poszczególni przedstawiciele prezentowali poglądy narodowe serbskie, ale znacząco różnili się w swoim stosunku do władz habsburskich. Wobec dużej polaryzacji poglądów politycznych, ich działalność koncentrowała się na postulatach wsparcia kredytowego dla Serbów z poszczególnych części monarchii. Jednocześnie, wraz z upowszechnianiem działalności finansowej propagowano serbską ideologię

${ }^{25}$ Por. W Owoc (ks.), Rzut oka na kasy systemu Raffeisena, Rzeszów 1898. Więcej o tym rozwiązaniu na gruncie serbskim: D. Gnjatović, Zemljoradničke kreditne zadruge: prve institucije za finansiranje razvoja poljoprivrede u Srbiji. „Bankarstvo” 2010, nr 3-4; s. 16-18.

${ }^{26}$ Por. D. Jelić, Sailing with the nationalist wind: the case of the Serbian bank in Zagreb (18951918), w: The creators and the creation of banking enterprises in Europe from the 18th to the 20th centu$r y$, red. Kostas P. Kostis, Athens 2002, s. 148, 164-165.

${ }^{27}$ Rok po stworzeniu serbskiego banku w Zagrzebiu powstał bank handlowy w Zemunie, a od 1897 roku sieć mniejszych serbskich banków kredytowych, koncentrujących się na żupanii sremskiej. W 1899 roku powstał bank kredytowy w Karlovcach i towarzystwa kredytowe w Bjelovarze i Vukovarze, które wkrótce zamieniły \się banki. Na początku 20 wieku w rękach serbskich było ogółem sześć banków, 15 kas oszczędnościowych i 13 spółdzielni pieniężnych. Poza Sremem, serbskie kasy oszczędnościowe powstały w Gospiciu i Korenicy (Lika-Krbava; 1897-1898), Pakracu i Kostajnicy (1898); N. Rumenjak, Politička i društvena elita Srba, s. 490-493; N. Gaćeša, Srpske novčane ustanove, s. 125. 
narodową. Nacisk na aktywizację ekonomiczną serbskich elit w żupaniach najliczniej zamieszkanych przez Serbów, sremskiej i licko-krbawskiej, wynikał z przekonania środowiska związanego z bankiem serbskim z Zagrzebia, że ludność ta powinna jak najszybciej stworzyć jednolitą wspólnotę polityczną, walczącą o swoje interesy ekonomiczne i polityczne w Austro-Węgrzech. V. Matijević, jeden z dyrektorów banku i jednocześnie przedstawiciel partii autonomistycznej, uważał, że dynamiczne działania w kierunku upowszechnienia kapitału obrotowego oraz inwestycyjnego, stanowiły punkt wyjścia dla wydobycia ziem zamieszkanych przez Serbów z marazmu gospodarczego. Tworzenie sieci powiązań instytucjonalnych za pośrednictwem przedstawicieli banku i współpracujących z nim towarzystw oraz spółdzielni rolnych miało być kluczem do ekspansji banku i odniesienia sukcesu finansowego. Jednocześnie struktury bankowe stanowiły punkt odniesienia dla innych inicjatyw, nastawionycyh na aktywizację poszczególnych grup społecznych, związanych z ludnością serbską. Szczególna rola w tym względzie przypadła stowarzyszeniom, powołanym w celu rozwijania serbskiej spółdzielczości, promowania nowoczesnych form gospodarki i edukacji zawodowej wśród Serbów (Związek Serbskich Spółdzielni Rolniczych z Austro-Wegier; Savez srpskih zemljoradničkih zadruga; 1898 i Centralna Kasa Serbskich Spółdzielni Gospodarczych; Centralna kasa srpskih privrednih zadruga; 1898). W ich ramach rozwijano kontakty z lokalnymi środowiskami społeczno-gospodarczymi, które lokowały swoje środki na rachunkach oszczędnościowych banku z Zagrzebia ${ }^{28}$. Jeśli w danym rejonie brakowało takich przedsięwzięć, starano się je aranżować za pomocą struktur współpracujących z bankiem. Ten czuwał nad działalnością poszczególnych jednostek, unikając jednak nadmiernej centralizacji tej struktury. Tworzenie sieci powiązań instytucjonalnych, mających stabilną podstawę ekonomiczną i zróżnicowaną formułę, było kluczowe dla sukcesu finansowego ${ }^{29}$.

Ideą działalności banku serbskiego było przyciągnięcie do jego struktur ludzi młodych, rozwijających działalność handlową, rzemieślniczą lub rolniczą w oparciu o nowoczesne rozwiązania. Zamysłem V. Matijevicia było także upowszechnienie edukacji zawodowej wśród ludności wiejskiej. Z tą myślą zostało powołane serbskie towarzystwo gospodarcze Privrednik (1897-1946), które organizowało praktyczne szkolenia dla dzieci i młodzieży serbskiego pochodzenia, m.in. w zakresie rzemiosła oraz pośredniczyło w kontaktach $\mathrm{z}$ pracodawcami ${ }^{30}$. W ramach organizacji stwo-

28 Predstavka Saveza Srpskih zemljoradničkih zadruga i Centralne kase Srpskih privrednih zadruga, Privrednik, br. 17, Zagreb, 1899, 275.

${ }^{29}$ D. Jelić, Sailing with the nationalist wind, s. 156-157, s. 166; M. Artuković, Srpska, gospodarska, kulturna, prosvjetna i humanitarna društva, ,Suvremena povijest” 1999, t. 31, nr 3, s. 495-500.

30 Por. Српско привредно друштво „Привредник“, списак питомаца (1897-1902); http://baza. privrednik.net/privrednik.php [dostęp: 15.11.2018]; P. V. Krestić, Specifičan vid obrazovanja - Srpsko privredno društvo Privrednik (1897-1918), Obrazovanje kod Srba kroz vekove, Beograd 2003, s. 139141; M. Kolar-Dimitrijević, Srpsko društvo Privrednik i osposobljavanje djece dvorskog kotara u zanatstvu, trgovini i ugostiteljstvu 1897-1941. godine, w: Dvor na Uni, red. M. Joka, Dvor na Uni, 1991, s. 257-264. 
rzono system sypendialny, dedykowany dla młodych osób serbskiego pochodzenia, pochodzących z niższych warstw społecznych. Ważną rolę w propagowaniu przedsiębiorczości i edukacji wśród Serbów odegrało czasopismo „Privrednik” (1898), które jednocześnie było utożsamiane z poglądami serbskiego ruchu autonomistycznego. Istotnie, w dużej części materiały publikowane na łamach "Privrednika" były autorstwa osób związanych z partyjnym organem prasowym „Srbobran”. Nie wpłynęło to jednak zasadniczo na zaostrzenie kontrowersji politycznych wokół działalności finansnowej i społecznej banku. W gazecie ukazywaly się publikacje, w których propagowano hasła serbskiego ,patriotyzmu ekonomicznego". Bardziej zdecydowane wnioski formułowano na łamach "Srbobrana", gdzie nawoływano czytelników, aby w imię narodowej solidarności nie korzystali z usług instytucji finansnowych, kojarzonych z kapitałem niemieckim, węgierskim, żydowskim czy chorwackim ${ }^{31}$.

Środowiska finansowe zdawały sobie jednak sprawę, że warunkiem ich sukcesu finansowego było utrzymanie neutralności politycznej. Ona też stała się jednym z głównych wyznaczników działań banku, którego uwaga skoncentrowała się na obszarach wiejskich. W ocenie jego założycieli, władze węgierskie z niepokojem przyglądały się przede wszystkim sytuacji społeczno-politycznej miastach, które natenczas rozrastały się, rozwijały przemysłowo, stając się areną różnorodnych konfliktów. Wieś serbska była mniej zauważana przez rządzących i miała stosunkowo niewielki wpływ na ogólnopaństwowe przetargi polityczne. W tej sytuacji wystarczyło unikać jednoznacznych deklaracji, które mogły zaniepokoić rządzących i sprowokować ich do hamowania poczynań serbskiego banku z Zagrzebia na polu ekonomicznym czy społecznym. Z kolei środowisko kojarzone z V. Matijeviciem żywiło przekonanie, że bank powinien raczej szukać klientów identyfikujacych się z poglądami narodowymi aniżeli polityczno-partyjnymi. Sam V. Matijević przekonywał współpracowników z partii autonomistycznej, że aktywność finansowa na tym polu zaowocuje stworzeniem zaplecza politycznego dla młodego ugrupowania, walczącego o wpływy wśród Serbów. Właśnie obszar przyłączony do bańskiej Chorwacji w następstwie likwidacji Pogranicza stał się głównym celem ekspansji partii, która z trudem zdobywała poparcie wśród Serbów ze Sremu. Żupania sremska pozostawała na przełomie XIX i XX wieku domeną wpływów prowęgierskich lojalistów lub radykałów ${ }^{32}$.

${ }^{31}$ S. M., Da li je potrebno srpskom sveštenstvu i ekonomsko obrazovanje, „Privrednik” 1900, nr 20, s. 233-235; V. Krestić, Vreme u kome je nastao Privrednik, Spomen knjiga Srpskog privrednog društva »Privred- nik«1897-1947, Beograd 1984, s. 11-12. Rząd serbski miał partycypować finansowo w powołaniu czasopisma „Privrednik”, które miało być adresowane do serbskich odbiorców. Na założenie gazety przeznaczono prawdopodobnie 3 miliony ówczesnych dinarów. Za czasopismo odpowiadało serbskie stowarzyszenie społeczno-gospodarcze o tej samej nazwie; N. Rumenak, Počeci „Privrednika” u okrilju Matijevića i Srpske banke u Zagrebu, w: Srpsko privredno društvo, s. 31-32.

${ }^{32} \mathrm{~W}$ literaturze chorwackiej akcentuje się, że działalność ekonomiczna, inspirowana przez prominentnych polityków z partii autonomistycznej, stanowiła podstawę dla aktywizacji politycznej serbskiej ludności wokół haseł narodowych. Argument ekonomiczny w postaci kredytów lub pomocy finansowej stanowił jeden z elementów propagandy partyjnej i działań w kierunku zmiany więzi społecznych. Forsowano postulaty integracji wokół serbskich wartości narodowych, na podstawie unowocześnionych 
W rezultacie, w pierwszej dekadzie XX wieku, system stworzony wokół banku serbskiego z Zagrzebia, zaczęto traktować jako swoistą ideologiczną alternatywę dla tradycyjnej formuły życia społecznego Serbów pod kontrolą władz kościelnych. Poprzez swoją charakterystykę, jako organizacja zrzeszająca i kontrolująca szereg instytucji finansowych o różnym charakterze oraz zasięgu, zagrzebski bank urastał do roli nowoczesnej emanacji serbskich społeczności, żyjących w monarchii habsburskiej. Tworzył podstawy pod dalszą ewolucję wspólnoty narodowej, która od 11 lipca 1912 roku, wraz z likwidacją autonomii kościelnej została pozbawiona dotychczasowych przywilejów ${ }^{33}$. Z pewnością, zabiegi banku, polegające na kształtowaniu i propagowaniu narodowego przekazu wśród Serbów, wynikały nie tylko z wąsko pojętego rachunku ekonomicznego. Należy pamiętać, że w omawianym okresie, poza ograniczoną liczebnie elitą społeczną, wprzęgniętą w system instytucjonalny monarchii, Serbowie nie byli aktywni politycznie. Najszybciej mogli zintegrować się wokół wartości narodowych, które na dalszy plan odsuwały kwestie związane z różnicami społecznymi czy ekonomicznymi. Sytuacja ta umożliwiła wykrystalizowanie się systemu instytucji finansowych, które wbrew logice wolnego rynku opierały swoją działalość na swoistym ekskluzywizmie etnicznym.

Elity finansowe serbskie były uzależnione od działań i decyzji władz. Brak nowoczesnego przemysłu i wysokotowarowego rolnictwa uniemożliwiał pojawienie się lub przyciągnięcie znaczącego kapitału inwestycyjnego z zewnątrz. Brakowało środowisk, które mogłyby ten kapitał generować na miejscu w oparciu o nowoczesne metody wytwarzania. Miejscowa ludność nadal w większości funkcjonowała w tradycyjnych odniesieniach ekonomicznych, co ograniczało wpływ nowoczesnych ideologii politycznych na świadomość społeczno-polityczną jednostek. W warunkach dużego zróżnicowania etnicznego, szczególną siłę wyrazu zdobyły ideologie narodowe. Było to widoczne zarówno w sferze politycznej, jak i gospodarczej. Z drugiej strony, na przełomie XIX i XX wieku widoczne były jednak różnice w postrzeganiu celów i metod działan finansowych. Wąskie elity finansowe nadal czerpały korzyści $\mathrm{z}$ funkcjonowania $\mathrm{w}$ ścisłym kontakcie $\mathrm{z}$ państwem, jednocześnie poszerzając spektrum odbiorców dla swojej działalności bankowo-kredytowej. W warunkach ograniczonej modernizacji społeczno-ekonomicznej, sięgnięto po argument solidarności narodowej i w oparciu o to kształtowano przekaz.

Działalność Serbskiego Banku w Zagrzebiu umożliwiła stworzenie i utrwalenie ponadregionalnej sieci powiązań finansowych, obejmującej ludność serbską, rozsianą po różnych częściach monarchii habsburskiej. Model Raifeissena, zaadaptowany na miejscowym gruncie, był wdrażany z myślą o znalezieniu nowych odbiorców usług finansowych. Traktowano go także jako sposób na stopniową modernizację społeczno-ekonomiczną ludności, która pozostawała w tyle za innymi grupami etnicznymi

struktur gospodarczych; D. Jelić, Sailing with the nationalist wind, s. 163; M. Artuković, Ideologija srpsko-hrvatskich sporova (Srbobran 1884-1902), Zagreb 1991, s. 52.

${ }^{33}$ Срби у Хабзбурикој Монархији, s. 265. 
monarchii w procesie rozwoju gospodarczego. W warunkach monopolu politycznego, przyznanego w Austro-Węgrzech dwóm grupom narodowym, a także słabo rozwiniętego rynku wewnętrznego, handlu i przemysłu, miejscowe elity społeczno-polityczne podejmowały działania finansowe w imię narodowego korporatywizmu. Była to cecha charakterystyczna nie tylko dla ziem chorwackich. Można ją zaobserwować także w innych częściach ówczesnych Węgier, na obszarze rumuńskim czy słowackim $^{34}$. Wszędzie tam aktywizja i organizacja ekonomiczna miejscowej ludności nie mogła być wspierana wyłącznie przez procesy modernizacji gospodarczej. Ponadto, jak wskazują badania historyczne, ważkim problemem, dotyczącym stosunków finansowych na ziemiach chorwackich czy na terenie Bośni, było stosunkowo niewielkie zainteresowanie tymi rejonami ze strony ośrodków finansowych, dominujących w monarchii habsburskiej. Tymczasem w tych peryferyjnych prowincjach istniał zauważalny głód kapitału. Lokalne lub regionalne instytucje finansowe stanowiły odpowiedź na ten popyt, który nie został odpowiednio szybko dostrzeżony w Budapeszcie czy Wiedniu. W rezultacie, aktywizacja finansowa środowisk serbskich na przełomie XIX i XX wieku przebiegała w ścisłym powiązaniu z procesem ugruntowywania nowoczesnych ruchów politycznych, odwołujących się do ideologii narodowej.

\section{BIBLIOGRAFIA}

Artuković Mato, Ideologija srpsko-hrvatskich sporova (Srbobran 1884-1902), Zagreb 1991.

Artuković Mato, Srbi u Hrvatskoj: Statistički pokazatelji (1883.-1903.), „Časopis za suvremenu povijest” 2000, nr 1, s. 135-138.

Artuković, Mato, Srpska, gospodarska, kulturna, prosvjetna i humanitarna društva, „Časopis za suvremenu povijest" 1999, nr 3, s. 491-509.

Čepulo Dalibor, Hrvatska pravna povijest u europskom kontekstu od srednjeg vijeka do suvremenog doba, Zagreb 2016.

Gaćeša Nikola, Srpske novčane ustanove u drugoj polovici XIX i početkom XX veka u Hrvatskoj i Slavoniji, Zbornik o Srbima u Hrvatskoj, Beograd 1999, t. 4, s. 117-141.

Gnjatović Dragana, Zemljoradničke kreditne zadruge: prve institucije za finansiranje razvoja poljoprivrede u Srbiji. „Bankarstvo” 2010, nr 3-4, s.15-34.

Gross Mirjana, Szabo Agneza, "Prema hrvatskom građanskom društvu": društveni razvoj u civilnoj Hrvatskoj i Slavoniji šezdesetih i sedamdesetih godina 19. stoljeća, Zagreb 1992.

Grujić Radoslav M., Azbučnik Srpske pravoslavne crkve, Beograd 1993 [Груиђ Радослав, Азбучник Српске православне иркве, Београд 1993].

Hrvatski ustavni zakoni, Zagreb 1917.

Jelić Damir, Sailing with the nationalist wind: the case of the Serbian bank in Zagreb (1895-1918), w: The creators and the creation of banking enterprises in Europe from the 18th to the 20th century, red. Kostas P. Kostis, Athens 2002.

Kolar-Dimitrijević Mira, Srpsko društvo Privrednik i osposobljavanje djece dvorskog kotara u zanatstvu, trgovini i ugostiteljstvu 1897-1941. godine, w: Dvor na Uni, red. Mile Joka, Dvor na Uni 1991, s. $257-264$.

${ }^{34}$ D. Jelić, Sailing with the nationalist wind, s. 167. 
Krestić Petar V., Specifičan vid obrazovanja - Srpsko privredno društvo Privrednik (1897-1918), w: Obrazovanje kod Srba kroz vekove, Novi Sad 2003, s. 127-142.

Krestić Vasilije, Istorija Srba u Hrvatskoj i Slavoniji, Beograd 2010 [Крестић Василије, Историја Срба у Хрватској и Славонији, Београд 2010].

Krestić Petar, Vladimir Matijević i društvo "Privrednik", w: Srpsko privredno društvo "Privrednik". Kroz tri vijeka, red. Nikola Lunić, Jelena Tabaks, Zagreb 2009, s. 13-28.

Owoc W, Rzut oka na kasy systemu Raffeisena, Rzeszów 1898.

Pet godina rada Srpske banke, "Privrednik", 1900, nr 13, s. 154-155.

Predstavka Saveza Srpskih zemljoradničkih zadruga i Centralne kase Srpskih privrednih zadruga, „Privrednik” 1899, nr 17, s. 275.

Radenić Andrija, Položaj i borba seljaštva u Sremu od kraja XIX veka do 1914, Beograd 1958.

Rumenjak Nives, Politička i društvena elita Srba u Hrvatskoj potkraj 19. stoljeća : uspon i pad Srpskoga kluba, Zagreb, 2005.

S. M., Da li je potrebno srpskom sveštenstvu i ekonomsko obrazovanje, „Privrednik” 1900, nr 20, s. $233-$ 235.

Spomen knjiga Srpskog privrednog društva Privrednik 1897-1947, Beograd 1984.

Srbi u Habsburškoj Monarhiji od 1526. do 1918., Novi Sad 2016, t. 2.

Statistički godišnjak Kraljevina Hrvatske i Slavonije, 1905, Zagreb 1913, t. 1.

Statuti Srpske banke u Zagrebu; osnovana 1895. godine; http:/srpska-banka.com/Srpska\%20Banka/ STATUT.pdf [dostęp: 21.11.2018].

Szabo Agneza, Socijalna struktura srpskog stanovništva u Hrvatskoj i Slavoniji između 1880 i 1900. godine, w: Zbornik radova o povijesti i kultury srpskog naroda u Socijalistickoj Republici Hrvatskoj, Zagreb 1989, t. 2, s. 107-134. 
